\title{
Androgen Action in Prostate Cancer
}

\author{
Sujit Basu • Donald J. Tindall
}

Published online: 16 November 2010

(C) Springer Science+Business Media, LLC 2010

\begin{abstract}
Prostate cancer represents a major health problem in men worldwide. Androgens are required for the growth and maintenance of the prostate. Androgens act by binding to the androgen receptor (AR), a nuclear receptor transcription factor present in the prostate tissues. Most prostate tumors also retain their androgen dependence; therefore, androgen ablation is usually the preferred initial therapeutic approach for the treatment of advanced prostate cancer patients. This review summarizes the current information regarding the role of androgens in prostate cancer.
\end{abstract}

Keywords Androgen - Androgen ablation therapy · Prostate

\section{Introduction}

Prostate cancer is the most commonly diagnosed male cancer in the Western World [1]. Since activation of androgen receptors by androgens is required for the growth and survival of malignant prostate cells and because prostate cancer is usually androgen dependent in the beginning [2-5], androgen ablation therapy in the form of medical and or surgical castration is initially effective in inhibiting the growth of these tumors in most patients [3,5]. However, with time, the tumor recurs in an androgen-refractory

S. Basu

Department of Pathology, Ohio State University,

Columbus, OH 43210, USA

\section{J. Tindall $(\bowtie)$}

Departments of Urology and Biochemistry and Molecular

Biology, Mayo Clinic College of Medicine,

Rochester, MN 55905, USA

e-mail: tindall@mayo.edu manner, presenting with a more aggressive and metastatic phenotype, which is resistant to further hormonal manipulation and therefore called castration-resistant prostate cancer $[4,5]$. Since androgens play important roles in the growth and survival of prostate cancer cells [2-5], we will address the role of androgens in the development and progression of prostate cancer.

\section{Synthesis and Metabolism of Androgens}

Androgens are sex hormones, which regulate the differentiation and maturation of male reproductive organs, as well as development of male secondary characteristics [4]. Testosterone is the primary $(\sim 90 \%)$ circulating form of androgen [4]. The remaining androgens $(\sim 10 \%)$, which include dehydroepiandrosterone, androstenediol, and androstenedione are synthesized in the adrenal cortex, and are subsequently converted to testosterone in the peripheral tissues $[4,6]$. Testosterone production is tightly controlled by the hypothalamic-pituitary-gonadal axis and is produced primarily by the Leydig cells of the testes in response to the stimulation by luteinizing hormone $(\mathrm{LH})$ produced in the anterior pituitary [7]. LH release in turn is controlled by pulsatile secretion of LH-releasing hormone (LHRH) from the hypothalamus [7]. In addition, inhibitory signals also occur at the level of testosterone, which acts through a negative feedback loop to inhibit LHRH release by the hypothalamus and to decrease the sensitivity of the pituitary to LHRH [7]. Circulating testosterone is bound to serum proteins, e.g., sex hormone binding globulin and albumin, leaving only $1-2 \%$ as free testosterone [8].

Since testosterone is lipophilic, free testosterone can easily diffuse into the target cells and, upon entry, is rapidly converted to the more potent androgen, 5-alpha dihydrotestosterone 
(DHT), by the enzymes 5-alpha-reductase Type I $(5 \alpha \mathrm{R} 1)$ and 5 -alpha-reductase Type II $(5 \alpha \mathrm{R} 2)$ [9]. Although $5 \alpha \mathrm{R} 2$ has been considered traditionally to be important in the nonmalignant prostate, recent reports indicate that $5 \alpha \mathrm{R} 1$ has a major role in the development and progression of prostate cancer $[10,11]$. A number of studies have reported that $5 \alpha \mathrm{R} 1$ expression is greater in prostate cancer tissues in comparison to benign control tissues. In addition, expression and activity of $5 \alpha \mathrm{R} 2$ are also decreased [11-14].

\section{The Androgen Signaling Axis}

Testosterone and DHT mediate their actions by binding to AR, a $110-\mathrm{kDa}$ phosphoprotein and a member of the nuclear receptor transcription factor superfamily (Fig. 1) [15]. Similar to other steroid receptors, modular domains of the AR include an N-terminal transactivation domain (AF-1), a central zinc-finger DNA binding domain (DBD), and a Cterminal ligand-binding/transactivation domain (AF-2) [16]. However, DHT is more potent than testosterone because it dissociates more slowly from the AR and induces a conformation in AR that is more resistant to degradation $[16,17]$. In the basal, unliganded state, the AR exists in the cytoplasm in a complex with heat shock proteins (Hsp) and immunophilin chaperones such as Hsp90, 70, 56, and 23 [18]. This complex is critical for the generation of a highaffinity, ligand-binding conformation of the AR. Upon binding to androgen, there is a change in the conformation and composition of this complex, which leads to translocation of AR to the nucleus [19]. In the nucleus, the AR dimerizes and binds to androgen response elements (AREs), which are in the promoter and enhancer regions of various target genes [19]. In order to activate transcription of target genes, ARE-bound AR relies on the activity of coactivator proteins, which include the p160 family (SRC-1, GRIP1/ TIF2, RAC3/pCIP/ACTR/AIB1/TRAM1), P/CAF, CBP, Tip60, and p300. These coactivators possess intrinsic histone acetyltransferase (HAT) activity, which can be directed towards histone, as well as other proteins. Also, AR can specifically recruit the AR-associated (ARA) coactivators, ARA70, ARA55, and ARA54 [20]. These large multi-

Fig. 1 Schematic representation of androgen action in prostate cancer. $C R P C$ castrationresistant prostate cancer, $A R$ androgen receptor, $A R S$ androgen receptor signaling, $5 \alpha R 1 / 5 \alpha R 2$ 5-alpha-reductase Type I/5-alpha-reductase Type II, DHT 5-alpha dihydrotestosterone

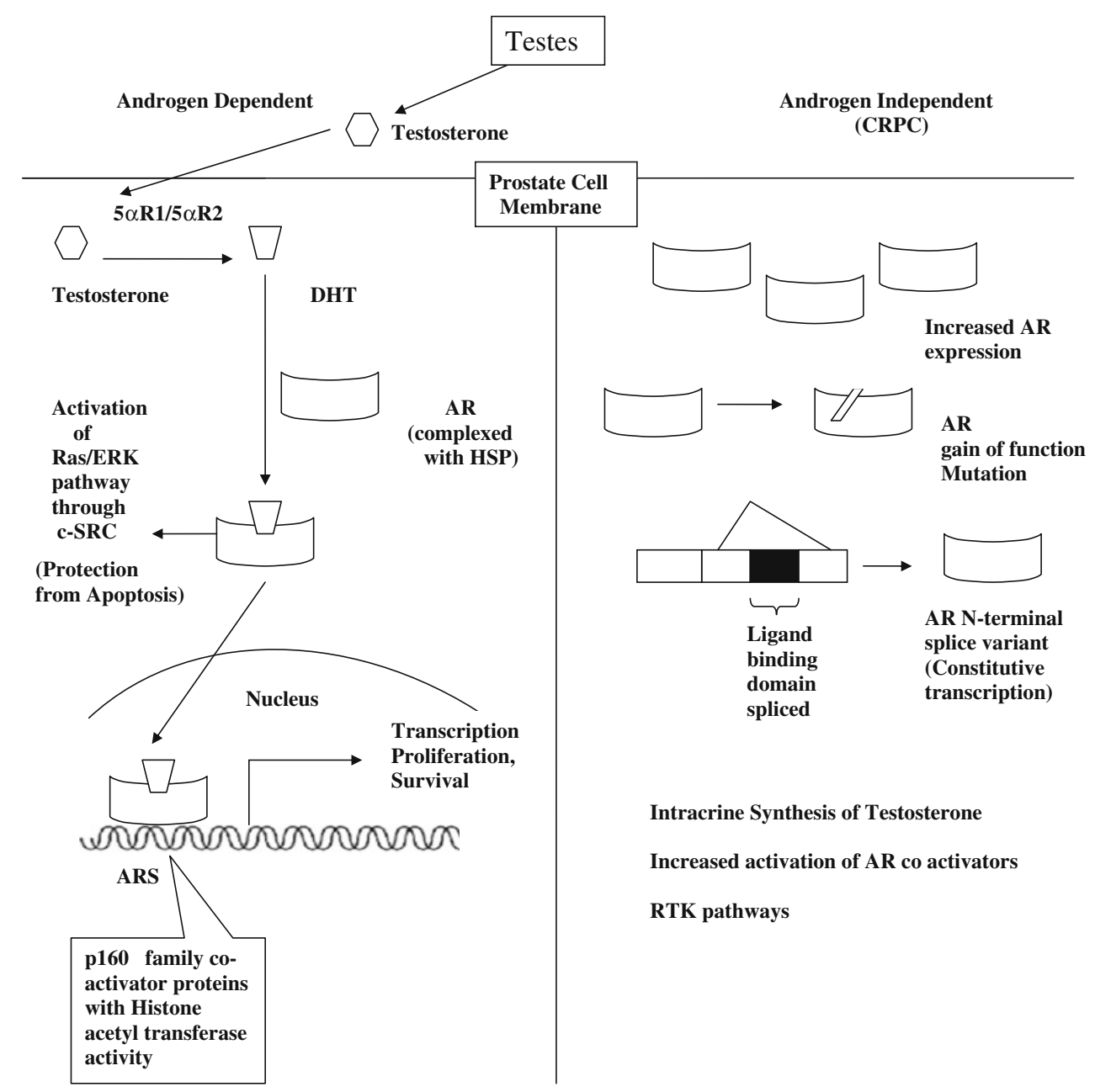


protein complexes interact with the basal transcriptional machinery to regulate the level of transcription in target genes [20].

A separate ligand-dependent, nongenotropic function of AR also exists. Androgen binding can result in ARmediated activation of the Ras/extracellular signal-related kinase (ERK) pathway through nongenotropic activation of the c-Src nonreceptor tyrosine kinase. In some types of cells, androgen stimulation induces complex formation between $\mathrm{AR}$ and $\mathrm{c}-\mathrm{Src}$, as well as the estrogen receptor (ER) $\beta$-subunit. Importantly, AR-mediated cSrc activation can lead to increased cellular proliferation and protection from apoptosis [15-25].

\section{Androgen Action in Non-malignant Prostate}

The prostate is a small chestnut-sized fibromuscular glandular male accessory reproductive organ located below the bladder and surrounding the urethra [4]. Prostatic secretions contribute to the major components of the seminal fluid that is released at ejaculation [4]. The basal and luminal epithelium of the prostate forms the glandular acini, which are separated by a basement membrane [4]. The epithelial cell compartment consists of basal cells lining the basement membrane, luminal columnar secretory cells, and a small number of neuroendocrine cells [4]. The lineage and differentiation of these epithelial cells are regulated by the surrounding stroma [26]. Androgens regulate several important functions within the epithelial compartment such as cellular proliferation, differentiation, as well as metabolic and secretory functions [4]. AR is expressed in both the epithelial and stromal cells in adult prostate gland [27]. Androgen deprivation induces prostate involution and loss of epithelial cells through apoptosis. However, the normal size and function of the prostate is regained through rapid proliferation and differentiation of stem cells in the basal epithelial cellular compartment following androgen stimulation [27]. The AR functions primarily to maintain the differential secretory function of prostate epithelial cells [28]. The androgen-dependent survival of the epithelial compartment is controlled mainly by paracrine factors modulated by the supporting AR positive stromal cells [28]. This intricate relationship between the epithelial and stromal compartments helps to maintain the homeostasis in the prostate gland so that only $0.2 \%$ prostatic epithelial cells either proliferate or undergo apoptosis per day [27].

\section{Circulating Androgens and Prostate Cancer}

The direct correlation between serum androgens, especially testosterone, and risk of prostate cancer stems from the landmark studies by Huggins and Hodges [29], who reported regression of metastatic prostate cancer after reduction of serum testosterone levels and progression of metastatic disease and symptoms in a patient who was treated with exogenous testosterone [29]. More recent work, however, suggests that low testosterone levels might be associated with worse clinical and pathological determinants of prostate cancer including an increased risk of prostate cancer, a worse 5-year biochemical relapse-free survival, higher Gleason score, increased percentage positive-core rate at biopsy, worse pathological stage, and increased risk of positive surgical margins [30]. In addition, the controversy regarding finasteride in the prevention of prostate cancer and testosterone replacement therapy in hypogonadal men further indicates the uncertainty of the association between androgen and prostate cancer [30, 34, 35]. However, recent longitudinal studies of aging demonstrate an increased risk of aggressive prostate cancer among older men with higher levels of free serum testosterone [30]. These reports have led to the development of at least two theories to explain the relationship between prostate cancer and serum testosterone levels: the "suppression theory", which proposes that prostate cancer cells secrete an androgen inhibitor, and the "saturation theory", which suggests that serum levels of androgens above a sufficiently low baseline are sufficient to stimulate growth of prostate cancer [30-33].

\section{Androgen Action in Prostate Cancer}

Because androgens are required for the growth and survival of malignant prostate cells, androgen ablation therapy either in the form of medical and or surgical castration is initially effective in inhibiting growth of these cancer cells in most of the patients as indicated by reduced expression of its target gene, prostate-specific antigen (PSA), and concomitant tumor regression [36]. However, these prostate cancer relapse with a more aggressive and metastatic phenotype that is resistant to hormonal therapy and ultimately cause death of the patient [37]. This stage of the disease is referred to as androgen-independent, androgen-refractory, androgen depletion-independent, or castration-resistant prostate cancer (CRPC) [38]. Although CRPC prostate cancer does not respond to androgen ablation, the AR still remains a critical factor for the growth and survival of the majority of these tumors [4, 16, 27, 36, 37]. Most CRPC prostate cancer tissues have high levels of AR expression $[4,39]$. In addition, the PSA gene is also expressed at this stage of the disease $[4,16]$. Targeted inhibition of the AR decreases PSA expression, cell proliferation, and survival in many cell-based models of CRPC prostate cancer [4], thereby indicating that CRPC prostate cancer cells continue 
to proliferate and survive through abnormal AR activation. Thus, the AR signaling axis appears to be a valid target for therapy in this stage of the disease [4].

\section{AR in Castration-Resistant Prostate Cancer}

Several mechanisms can reactivate the AR in prostate cancer patients following androgen ablation, including AR gene amplification and increased AR mRNA and protein levels, AR mutations, altered expression of AR-associated coregulators, AR splice variants, and cross talk between different signal transduction pathways [40-42].

AR gene amplification has been observed in approximately $30 \%$ castration-resistant patients with recurrent prostate cancer [42-44]. However, AR gene amplification does not always lead to an increase in AR protein levels [42-44]. Higher levels of AR protein can result from gene amplification and also from increased transcription rates, or stabilization of the mRNA or protein [42-44]. AR amplification is often detected in patients who initially respond to hormone treatment and is not observed in patients with early recurrence or no initial response. The median survival time in patients with AR amplification has been reported to be twice than those without AR amplification [42-44].

Increased AR expression sensitizes prostate cancer cells to low levels of androgen and promotes progression from hormone-dependent to CRPC [45]. Anti-androgens can also activate AR in these cells [45]. The mechanism for this activity is attributed to an alteration in the coactivator assembly on the promoter of AR-dependent target genes [45]. Since AR can regulate its own transcription, therefore it can also increase its synthesis by a feed-forward mechanism [45]. These mechanisms thus play critical roles in the pathogenesis of CRPC.

AR mutations have been identified in its ligand-binding domain, as well as the amino terminus and DNA-binding domain [46-48]. These mutations are usually related to AR gain-of-function and are linked to CRPC. In addition, the majority of AR mutations, which are associated with hormone ablation therapy, are in the C-terminal ligandbinding domain. These mutations increase the sensitivity of AR to low concentrations of androgens, weak androgen precursors, progesterone, estradiol, cortisol, and even antiandrogens. A common AR mutation is at codon 877 (Thr to Ser), detected in prostate cancer tissues biopsied from patients with metastasis [47]. A specific AR mutation at amino acid 741 (Trp to Cys or Trp to Leu) has been detected in patients receiving the anti-androgen drug, bicalutamide [49]. Other known AR mutations that display altered ligand-binding specificity are Q798E, M715V, and H874Y [47]. Some AR mutations outside the ligandbinding domain have also been detected in CRPC.
Mutation at amino acid 255 (E255K) interferes with interaction between AR and the E3 ubiquitin ligase, CHIP. This mutant AR further exhibits increased stability and nuclear localization in the absence of ligand [50].

Several coactivators such as p300, FHL2, TIF2, SRC1, TIP60, and BAG-1L are present at increased levels in CRPC [51]. The expressions of these coregulators directly or indirectly depend on the AR activity, and thereby suggest a feed-forward loop for the dysfunctional AR in CRPC. Furthermore, over-expression of these coactivators reduces the androgen requirement of AR for its activation and is considered a probable mechanism for the growth of prostate cancer after hormone ablation therapy. Furthermore, there is also a cross talk between growth factor kinase pathways and AR. Insulin-like growth factor-1 (IGF-1), epidermal growth factor (EGF), interleukin-6 (IL-6) and Wnt signaling, oncostatin (OSM), and ligands stimulating cAMPdependent protein kinase A (PKA) have been reported to enhance the activity of AR or its coactivators in CRPC [52].

The AF-1 region in the amino-terminal domain (NTD) of AR plays a primary role in AR-mediated gene expression in the castration-resistant stage [53]. One of the mechanisms by which CRPC cells may evade androgen ablation is synthesis of splice variants of AR, which lack the ligandbinding domain, but retain AR NTD [54]. In the absence of the ligand-binding domain at the AR C-terminus, the NTD drives constitutive transcriptional activity. Such splice variants lacking the ligand-binding domain have been detected in tissues isolated from patients with CRPC [5557]. Recently, Andersen et al. have developed a small molecule, EPI-001, which can block transactivation of NTD and is reported to be specific for inhibition of AR without attenuating the transcriptional activities of related steroid receptors [58].

\section{Modulation of Androgen-AR Axis in the Treatment of Prostate Cancer}

As androgens stimulate the growth and survival of prostate cancer cells, the goal of hormonal therapy in prostate cancer is to deprive these cancer cells of androgen so that they die due to apoptosis $[4,5]$. Therefore, regression of an androgendependent prostate tumor is induced either medically with luteinizing hormone-releasing hormone analogues or surgically by orchiectomy, which reduces the intracellular concentration of DHT [21]. This in turn results in the death of androgen-sensitive cancer cells $[4,5]$. Thus, androgen deprivation slows the progression of the tumor and enhances the quality of life. However, with time the disease inevitably recurs, and importantly, CRPC still remains dependent on the AR as discussed above [5]. 
Substantial levels of androgens have been measured in locally recurrent malignant prostate tumors and in intratumoral metastatic castration-recurrent prostate cancer tissues [5]. These androgens in turn bind to AR and subsequently stimulate expression of androgen-regulated genes such as PSA, which commonly precedes clinical failure. Moreover, although the source of these tissue androgens may be either adrenal or intratumoral, targeting AR signaling in CRPC patients after androgen deprivation therapy by further blocking adrenal enzymes engaged in the biosynthesis of testosterone and DHT has been shown to be effective [5]. Recently, abiraterone, a selective, steroidal irreversible inhibitor of CYP17 (17 hydroxylase/C17, 20lyase), which blocks enzymes critical for the synthesis of testosterone, has been evaluated in patients with CRPC. Early results have shown promise with greater than a 50\% decline in PSA levels in $67 \%$ of patients with advanced, CRPC, and objective radiologic responses in patients deriving no benefit from standard androgen ablation therapy [5]. Another means of decreasing active androgen levels in target tissues is through inhibition of $5 \alpha \mathrm{R}$ enzymes. Thus, finasteride, which primarily targets type 2 $5 \alpha \mathrm{R}$, and dutasteride, which inhibits both $5 \alpha \mathrm{R}$ isoenzymes, have been successfully used for the prevention of prostate cancer [5].

\section{Conclusion}

Androgens acting via AR play critical roles in the growth and survival of prostate cancer cells. However, there are distinct differences between the functions of androgens in normal and malignant prostate. Furthermore, although androgens promote differentiation in normal prostate, these hormones stimulate oncogenic potential in prostate cancer cells [2]. As androgen plays a critical role in prostate carcinogenesis, the androgen signaling axis is an important therapeutic target in prostate cancer patients.

Conflict of Interest The authors declare that they have no conflict of interest.

\section{References}

1. Jemal A, Siegel R, Ward E, Hao Y, Xu J, Murray T, Thun MJ (2008) Cancer statistics, 2008. CA Cancer J Clin 58:71-96

2. Isaacs JT (1994) Role of androgens in prostatic cancer. Vitam Horm 49:433-502

3. Figg WD, Feuer JA, Bauer KS (1997) Management of hormonesensitive metastatic prostate cancer. Update on hormonal therapy. Cancer Pract 5:258-263

4. Dehm SM, Tindall DJ (2006) Molecular regulation of androgen action in prostate cancer. J Cell Biochem 99:333-344
5. Kohli M, Tindall DJ (2010) New developments in the medical management of prostate cancer. Mayo Clin Proc 85:77-86

6. Labrie F, Luu-The V, Labrie C, Simard J (2001) DHEA and its transformation into androgens and estrogens in peripheral target tissues: intracrinology. Front Neuroendocrinol 22:185-212

7. Amory JK, Bremner WJ (2003) Regulation of testicular function in men: implications for male hormonal contraceptive development. J Steroid Biochem Mol Biol 85:357-361

8. Hammond GL, Avvakumov GV, Muller YA (2003) Structure/function analyses of human sex hormone-binding globulin: effects of zinc on steroid-binding specificity. J Steroid Biochem Mol Biol 85:195-200

9. Zhou ZX, Lane MV, Kemppainen JA, French FS, Wilson EM (1995) Specificity of ligand-dependent androgen receptor stabilization: receptor domain interactions influence ligand dissociation and receptor stability. Mol Endocrinol 9:208-218

10. Tindall DJ, Rittmaster RS (2008) The rationale for inhibiting 5alpha-reductase isoenzymes in the prevention and treatment of prostate cancer. J Urol 179:1235-1242

11. Thomas LN, Douglas RC, Vessey JP, Gupta R, Fontaine D, Norman RW, Thompson IM, Troyer DA, Rittmaster RS, Lazier CB (2003) 5alpha-reductase type 1 immunostaining is enhanced in some prostate cancers compared with benign prostatic hyperplasia epithelium. J Urol 170:2019-2025

12. Luo J, Dunn TA, Ewing CM, Walsh PC, Isaacs WB (2003) Decreased gene expression of steroid 5 alpha-reductase 2 in human prostate cancer: implications for finasteride therapy of prostate carcinoma. Prostate 57:134-139

13. Thomas LN, Lazier CB, Gupta R, Norman RW, Troyer DA, O'Brien SP et al (2005) Differential alterations in 5alphareductase type 1 and type 2 levels during development and progression of prostate cancer. Prostate 63:231

14. Titus MA, Gregory CW, Ford OH 3rd, Schell MJ, Maygarden SJ, Mohler JL (2005) Steroid 5alpha-reductase isozymes I and II in recurrent prostate cancer. Clin Cancer Res 11:4365

15. Lamb DJ, Weigel NL, Marcelli M (2001) Androgen receptors and their biology. Vitam Horm 62:199-230

16. Heinlein CA, Chang C (2004) Androgen receptor in prostate cancer. Endocr Rev 25:276-308

17. Wright AS, Thomas LN, Douglas RC, Lazier CB, Rittmaster RS (1996) Relative potency of testosterone and dihydrotestosterone in preventing atrophy and apoptosis in the prostate of the castrated rat. J Clin Invest 98:2558-2563

18. Pratt WB, Toft DO (1997) Steroid receptor interactions with heat shock protein and immunophilin chaperones. Endocr Rev 18:306360

19. Shang Y, Myers M, Brown M (2002) Formation of the androgen receptor transcription complex. Mol Cell 9:601-610

20. Näär AM, Lemon BD, Tjian R (2001) Transcriptional coactivator complexes. Annu Rev Biochem 70:475-501

21. Migliaccio A, Castoria G, Di Domenico M, de Falco A, Bilancio A, Lombardi M, Barone MV, Ametrano D, Zannini MS, Abbondanza C, Auricchio F (2000) Steroid-induced androgen receptor-oestradiol receptor beta-Src complex triggers prostate cancer cell proliferation. EMBO J 19:5406-5417

22. Kousteni S, Bellido T, Plotkin LI, O'Brien CA, Bodenner DL, Han L, Han K, DiGregorio GB, Katzenellenbogen JA, Katzenellenbogen BS, Roberson PK, Weinstein RS, Jilka RL, Manolagas SC (2001) Nongenotropic, sex-nonspecific signaling through the estrogen or androgen receptors: dissociation from transcriptional activity. Cell 104:719-730

23. Kousteni S, Han L, Chen JR, Almeida M, Plotkin LI, Bellido T, Manolagas SC (2003) Kinase-mediated regulation of common transcription factors accounts for the bone-protective effects of sex steroids. J Clin Invest 111:1651-1664

24. Unni E, Sun S, Nan B, McPhaul MJ, Cheskis B, Mancini MA, Marcelli M (2004) Cancer Res 64:7156-7168 
25. Castoria G, Lombardi M, Barone MV, Bilancio A, Di Domenico M, Bottero D, Vitale F, Migliaccio A, Auricchio F (2003) Androgen-stimulated DNA synthesis and cytoskeletal changes in fibroblasts by a nontranscriptional receptor action. J Cell Biol 161:547-556

26. Sung SY, Chung LW (2002) Prostate tumor-stroma interaction: molecular mechanisms and opportunities for therapeutic targeting. Differentiation 70:506-521

27. Litvinov IV, De Marzo AM, Isaacs JT (2003) Is the Achilles' heel for prostate cancer therapy a gain of function in androgen receptor signaling? J Clin Endocrinol Metab 88:2972-2982

28. Kurita T, Wang YZ, Donjacour AA, Zhao C, Lydon JP, O'Malley BW, Isaacs JT, Dahiya R, Cunha GR (2001) Paracrine regulation of apoptosis by steroid hormones in the male and female reproductive system. Cell Death Differ 8:192-200

29. Huggins C, Hodges CV (1941) Studies on prostatic cancer: I. The effect of castration, of estrogen and of androgen injection on serum phosphatases in metastatic carcinoma of the prostate. Cancer Res 1:293-297

30. Pierorazio PM, Ferrucci L, Kettermann A, Longo DL, Metter EJ, Carter HB (2010) Serum testosterone is associated with aggressive prostate cancer in older men: results from the Baltimore Longitudinal Study of Aging. BJU Int 105:824-829

31. Miller LR, Partin AW, Chan DW, Bruzek DJ, Dobs AS, Epstein JI, Walsh PC (1998) Influence of radical prostatectomy on serum hormone levels. J Urol 160:449-453

32. Schaeffer EM, Walsh PC (2004) Risks of testosterone replacement. N Engl J Med 350:2004-2006

33. Fowler JE Jr, Whitmore WF Jr (1981) The response of metastatic adenocarcinoma of the prostate to exogenous testosterone. J Urol $126: 372-375$

34. Thompson IM, Goodman PJ, Tangen CM, Lucia MS, Miller GJ, Ford LG, Lieber MM, Cespedes RD, Atkins JN, Lippman SM, Carlin SM, Ryan A, Szczepanek CM, Crowley JJ, Coltman CA Jr (2003) The influence of finasteride on the development of prostate cancer. N Engl J Med 349:215-224

35. Rhoden EL, Morgentaler A (2004) Risks of testosteronereplacement therapy and recommendations for monitoring. $\mathrm{N}$ Engl J Med 350:482-492

36. Feldman BJ, Feldman D (2001) The development of androgenindependent prostate cancer. Nat Rev Cancer 1:34-45

37. Grossmann ME, Huang H, Tindall DJ (2001) Androgen receptor signaling in androgen-refractory prostate cancer. J Natl Cancer Inst 93:1687-1697

38. Roy-Burman P, Tindall DJ, Robins DM, Greenberg NM, Hendrix MJ, Mohla S, Getzenberg RH, Isaacs JT, Pienta KJ (2005) Androgens and prostate cancer: are the descriptors valid? Cancer Biol Ther 4:4-5

39. Buchanan G, Irvine RA, Coetzee GA, Tilley WD (2001) Contribution of the androgen receptor to prostate cancer predisposition and progression. Cancer Metastasis Rev 20:207-223

40. Dehm SM, Tindall DJ (2005) Regulation of androgen receptor signaling in prostate cancer. Expert Rev Anticancer Ther 5:63-74

41. Attar RM, Takimoto CH, Gottardis MM (2009) Castrationresistant prostate cancer: locking up the molecular escape routes. Clin Cancer Res 15:3251-3255

42. Scher HI, Sawyers CL (2005) Biology of progressive, castrationresistant prostate cancer: directed therapies targeting the androgenreceptor signaling axis. J Clin Oncol 23:8253-8261

43. Visakorpi T, Hyytinen E, Koivisto P, Tanner M, Keinänen R, Palmberg C, Palotie A, Tammela T, Isola J, Kallioniemi OP (1995) In vivo amplification of the androgen receptor gene and progression of human prostate cancer. Nat Genet 9:401-406
44. Bubendorf L, Kononen J, Koivisto P, Schraml P, Moch H, Gasser TC, Willi N, Mihatsch MJ, Sauter G, Kallioniemi OP (1999) Survey of gene amplifications during prostate cancer progression by high-throughout fluorescence in situ hybridization on tissue microarrays. Cancer Res 59:803-806, Erratum in: Cancer Res 1999; 59:1388

45. Chen CD, Welsbie DS, Tran C, Baek SH, Chen R, Vessella R, Rosenfeld MG, Sawyers CL (2004) Molecular determinants of resistance to antiandrogen therapy. Nat Med 10:33-39

46. Taplin ME, Rajeshkumar B, Halabi S, Werner CP, Woda BA, Picus J, Stadler W, Hayes DF, Kantoff PW, Vogelzang NJ, Small EJ (2003) Cancer and Leukemia Group B Study 9663. J Clin Oncol 21:2673-2678

47. Taplin ME, Bubley GJ, Shuster TD, Frantz ME, Spooner AE, Ogata GK, Keer HN, Balk SP (1995) Mutation of the androgenreceptor gene in metastatic androgen-independent prostate cancer. N Engl J Med 332:1393-1398

48. He B, Gampe RT Jr, Hnat AT, Faggart JL, Minges JT, French FS, Wilson EM (2006) Probing the functional link between androgen receptor coactivator and ligand-binding sites in prostate cancer and androgen insensitivity. J Biol Chem 281:6648-6663

49. Duff J, Davies P, Watt K, McEwan IJ (2006) Structural dynamics of the human androgen receptor: implications for prostate cancer and neurodegenerative disease. Biochem Soc Trans 34:1098-1102

50. Steinkamp MP, O’Mahony OA, Brogley M, Rehman H, Lapensee EW, Dhanasekaran S, Hofer MD, Kuefer R, Chinnaiyan A, Rubin MA, Pienta KJ, Robins DM (2009) Treatment-dependent androgen receptor mutations in prostate cancer exploit multiple mechanisms to evade therapy. Cancer Res 69:4434-4442

51. Heemers HV, Tindall DJ (2007) Androgen receptor (AR) coregulators: a diversity of functions converging on and regulating the $\mathrm{AR}$ transcriptional complex. Endocr Rev 28:778-808

52. Kaarbø M, Klokk TI, Saatcioglu F (2007) Androgen signaling and its interactions with other signaling pathways in prostate cancer. Bioessays 29:1227-1238

53. Dehm SM, Tindall DJ (2006) Ligand-independent androgen receptor activity is activation function-2-independent and resistant to antiandrogens in androgen refractory prostate cancer cells. J Biol Chem 281:27882-27893

54. Dehm SM, Schmidt LJ, Heemers HV, Vessella RL, Tindall DJ (2008) Splicing of a novel androgen receptor exon generates a constitutively active androgen receptor that mediates prostate cancer therapy resistance. Cancer Res 68:5469-5477

55. Hu R, Dunn TA, Wei S, Isharwal S, Veltri RW, Humphreys E, Han M, Partin AW, Vessella RL, Isaacs WB, Bova GS, Luo J (2009) Ligand-independent androgen receptor variants derived from splicing of cryptic exons signify hormone-refractory prostate cancer. Cancer Res 69:16-22

56. Guo Z, Yang X, Sun F, Jiang R, Linn DE, Chen H, Chen H, Kong X, Melamed J, Tepper CG, Kung HJ, Brodie AM, Edwards J, Qiu Y (2009) A novel androgen receptor splice variant is up-regulated during prostate cancer progression and promotes androgen depletion-resistant growth. Cancer Res 69:2305-2313

57. Sun S, Sprenger CC, Vessella RL, Haugk K, Soriano K, Mostaghel EA, Page ST, Coleman IM, Nguyen HM, Sun H, Nelson PS, Plymate SR (2010) Castration resistance in human prostate cancer is conferred by a frequently occurring androgen receptor splice variant. J Clin Invest 120:2715-2730

58. Andersen RJ, Mawji NR, Wang J, Wang G, Haile S, Myung JK, Watt K, Tam T, Yang YC, Bañuelos CA, Williams DE, McEwan IJ, Wang Y, Sadar MD (2010) Regression of castrate-recurrent prostate cancer by a small-molecule inhibitor of the amino-terminus domain of the androgen receptor. Cancer Cell 17:535-546 